\title{
25. Lexico-Phraseological features in English Language Teaching
}

\section{Halil KÜÇÜKLER ${ }^{1}$}

\section{Marina MURZACí2}

APA: Küçükler, H.; Murzaci, M. (2021) Lexico-Phraseological features in English Language Teaching. RumeliDE Dil ve Edebiyat Araștırmaları Dergisi, (Ö9), 307-328. DOI: 10.29000/rumelide.984779.

\begin{abstract}
The term "phraseology" is derived from the Greek words phrasis-speech and logos-teaching. Phraseological units cover a lot of drawbacks of the English language and it is one-third part of the colloquial speech. The aim of the study is to consider phraseological units as a means of communication and to explore their theoretical and practical meanings in the formation of students' oral-speech skills. The study was carried in in Gagauzia in Moldova, at the secondary school Yessentuki MOU SOSH № 4, where the methodological association of teachers is represented quite a lot and studied 4 four weeks. Qualitative research methods were utilized. Foreign language teachers at their meetings make reports on the improvement of the pedagogical process, on the introduction of new techniques, talk about new professional literature and the possibilities of its use by both teachers and students. The themes of integrated and non-traditional lessons are discussed, which pursue not only teaching but also educational objectives aimed at the all-round development of the personality. During the test in the control group students showed the following result: $10 \%$ of students made $1-5$ mistakes, $90 \%$ of students made more than 5 mistakes (the first application). In the second application all pupils gave wrong answers, i.e. $100 \%$ of pupils made more than 5 mistakes. Consequently, the developed phraseological set of exercises is effective for use at the secondary level of school.
\end{abstract}

Keywords: Phraseology, foreign language teaching, phrases

\section{Yabancı dil öğretiminde deyișbilim}

\section{Öz}

"Deyişbilim" terimi, Yunanca sözcükler-konuşma ve logo-öğretme sözcüklerinden türetilmiştir. Çalışmanın amacı, deyimsel iafadeleri bir iletişim aracı olarak ele almak ve öğrencilerin sözlü konuşma becerilerinin oluşumunda teorik ve pratik anlamlarını keşfetmektir. Deneysel çalışma, Moldova'daki Gagauzya'da, öğretmenlerin metodolojik birliğinin oldukça fazla temsil edildiği Yessentuki MOU SOSH № 4 ortaokulunda gerçekleștirilmiștir ve dört hafta sürmüștür. Nitel araştırma metodları kullanılmıştır. Yabancı dil öğretmenleri toplantılarında, pedagojik sürecin iyileştirilmesi, yeni tekniklerin tanıtılması hakkında raporlar sunar, yeni profesyonel literatür ve hem öğretmenler hem de öğrenciler tarafından kullanım olanakları hakkında konuşur. Sadece öğretimi değil, aynı zamanda kişiliğin çok yönlü gelişimini amaçlayan eğitim hedeflerini de takip eden entegre ve geleneksel olmayan derslerin temaları tartışılmaktadır. Kontrol grubundaki öğrenciler test sırasında șu sonucu ortaya çıktı: Öğrencilerin \%10'u 1-5 hata yaptı, öğrencilerin \%90'ı 5'ten fazla hata yaptı (ilk uygulamada) İkinci uygulamada tüm

Dr. Öğr. Gör., Balıkesir Üniversitesi, Yabancı Diller Yüksekokulu (Balıkesir, Türkiye), hkucukler2@gmail.com, ORCID ID: 00000002-7674-540X, [Araştırma makalesi, Makale kayıt tarihi: 26.07.2021-kabul tarihi: 20.08.2021; DOI: 10.29000/rumelide.984779]

2 YL, Komrat Devlet Üniversitesi, Yabanc1 Diller, (Komrat, Moldova), ORCID ID: 0000-0003-1308-2124 m.murzakoi719981998@mail.ru

RumeliDE Dil ve Edebiyat Araştırmaları Dergisi Osmanağa Mahallesi, Mürver Çiçeği Sokak, No:14/8 Kadıköy - ISTANBUL / TÜRKIYE 34714 e-posta: editor@rumelide.com tel: +90 $5057958124,+902167730616$
Address

RumeliDE Journal of Language and Literature Studies

Osmanağa Mahallesi, Mürver Çiçeği Sokak, No:14/8

Kadıköy - ISTANBUL / TURKEY 34714

e-mail: editor@rumelide.com

phone: +90 505 7958124, +90 2167730616 
öğrenciler yanlış cevaplar verdi, yani öğrencilerin \%100'ü 5'ten fazla hata yaptı. Sonuç olarak, geliştirilen deyişsel ifade egzersiz seti ortaokul düzeyinde kullanım için etkilidir.

Anahtar kelimeler: Deyișbilim, yabancı dil öğretimi, deyișler

\subsection{Introduction}

In most countries around the world, English is widely used in diplomacy, business and commercial documents. It is one of the five official languages of the United Nations, along with French, Spanish, Russian and Chinese. English is the working language of the UN General Assembly and Security Council. English is the language of commerce, as all large firms give instructions for their products in English, the language of international communication and the Internet. The origin of idioms is closely connected with people's mentality. English cannot be considered full of value without idiomatic usage. Idiomatic sentences enrich a language and the knowledge of idioms signal that the speaker knows the language on the level of a native speaker. The belles-lettres investigated by us revealed a great number of idiomatic sentences used by prominent writers in their works to make their language more expressive and colourful.

\subsection{The origin of phraseological units in modern English}

The term "phraseology" is derived from the Greek words phrasis-speech and logos-teaching. This term denotes a section of linguistics that is devoted to the study of the phraseological composition of the language, i.e. the subject of this science is the semantic, morphological and stylistic properties of phraseological units. Phraseology is also called a set of phraseological units inherent in a particular language, any writer or literary work. Phraseology deals with the study of the phraseological composition of the language (Atkinson, 20101: 320).

Phraseology is engaged in the development of methods for the study of phraseological units, their selection, classification and phraseography - descriptions in dictionaries. This science is studying the primary, original forms and meanings of phraseological units, determining their sources for all available monuments. She also tries to identify the spheres of their use in different eras of the existence of the language, as well as to establish the volumes of the phraseological composition and the system of ordering in a particular historical epoch of the development of the language (Arnold, 2010:220).

In a phraseological system, the language is a phraseological unit. Stable phrases or expressologisms provide unified combinations of words that have a single integral meaning and perform one syntactic function. The stability of a phraseological combination is understood as the lexical composition assigned to it, and expressiveness is the presence of an emotional and evaluative coloration. These phrases are used in speech in the form of a ready-made lexical unit and having a general meaning, which often has little meaning in it. (Asomova, 1963: 111)

\subsection{Phraseology as an object of linguistic research}

A.V. Kunin distinguishes seven main types of phraseologicalization depending on the linguistic material, which formed the basis of the future phrase, preceding the stage of potential phraseology, and the method of its phraseologicalization, taking into account both linguistic and extra linguistic factors:

1) the formation of a phrase by reinterpreting variable word combinations;

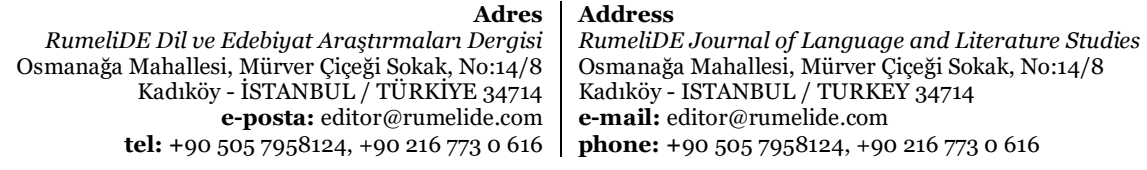


2) the formation of phrases by reinterpreting stable combinations of non-phraseological nature;

3) the formation ofphraseological expressions on the basis of potential phraseological units;

4) formation of phrases from the author's phrases;

5) formation of phrases on the basis of the plot, but not the combination of words;

6) formation of the phrases by puns of homonyms;

7) formation of the phrases from the phrases (phraseological derivation) (Kunin, 1996: 9).

The first six types refer to primary phraseologicalization, and phraseological derivation to secondary.

I. Formation of phrases by reinterpreting variable word combinations.

This type of phraseologicalization is the most common and represents a complete or partial reinterpretation of variable word combinations and sentences, i.e. one or another departure from the literal meaning of their components.

1. Complete reinterpretation of variable word combinations.

The phrases that emerged as a result of complete reinterpretation of variable combinations can be: big wig - an important person (lit. big wig); burn one's fingers - to burn on something (lit. burn one's fingers).

\section{Partial reinterpretation of variable word combinations.}

This phenomenon is much rarer in English than the one presented above. Examples are the phrases: a copybook maxim - the uppercase truth (lit. notebook aphorism); death-bed repentance - belated remorse (lit. deathbed repentance). The first component of the given phrases is a compound word.

\section{Rethinking of variable sentences}

In addition to the variable phrases, sentences can also be reinterpreted, for example: that cock won't fight this number won't fight (lit. this cock won't fight) or breakers ahead! - danger! watch out! (lit. storms ahead) (Kunin, 1996: 249).

II Formation of the phrases by reinterpreting the stable combinations of non-phraseological nature. Many $\mathrm{PE}$ are created through the reinterpretation of stable combinations of a non phraseological nature. These include, for example, professionalisms and terms used in their literal meaning. For example: hold in leash to keep in check, in obedience (lit. hold on the hounds); go off at half-cock - act or speak hastily, thoughtlessly (lit. shoot from half-cock, from half-cock) (Kunin, 2008:49).

The phrase formed as a result of the rethinking of stable combinations of non phraseological nature passes through four stages of development:

a) the stage of potential stability of the nephraseologicalcharacter;

b) the stage of stability of the nephraseologicalcharacter;

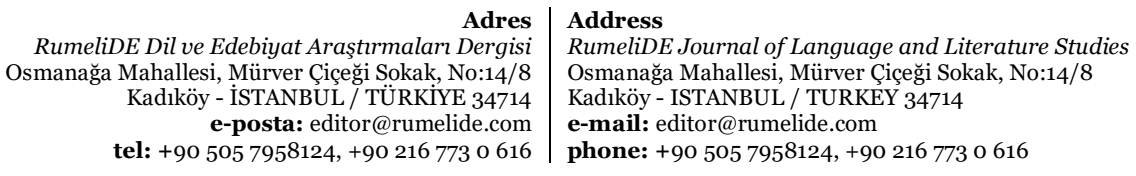


c) the stage of potential phraseological stability;

d) the stage of phraseological stability.

III. Formation of the phrases on the basis of potential phraseology.

Many PE have a stage of reinterpretation of a variable word combination or a stable word combination of a non-phraseological nature. These phrases arise as a result of the reinterpretation of the words included in their composition. Phrases arising in this way have only one preliminary stage of development - the stage of potential phraseological character. This usually applies to phrases based on an unreal image, the generation of a person's imagination.

1. The phraseological unit is based on an unreal image: one's wings are sprouting-jokingly, he (she, etc.) is not of this world, it is a real angel (lit. wings are coming through). Enough to make the angels weep involuntarily tears come up, at least someone will cry (lit. will make the angels cry, too) (Kunin, 1996: 319).

2. Phraseological hyperbole and understatement: make a mountain out of a molehill (lit. make a mountain out of a molehill). Examples of phraseological understatements are the following turns: a bit of all right colloquially what is necessary; not half - colloquially in the highest degree, terrible, desperate.

3. Phrases with different stylistic coloring:

a) ironic turns: have a soul above buttons - to consider the work performed beneath one's dignity; a fat lot of - a little, very little; (Smith, 2008: 39).

b) humorous turns of phrase: the clerk of the weather (an imaginary official who regulates the weather); in one's birthday suit - in the nude (cf.: in his mother's clothes) (Kunin, 1996: 244).

c) rude expressions: Damn your eyes! - Damn your eyes!

d) familiar turns of phrase: Has the cat got your tongue? - Did you swallow your tongue?

\section{I.3 Different approaches to the classification of phraseological units}

V.V. Vinogradov calls phraseological combinations stable combinations with partially reinterpreted meaning, in which each of the components, while remaining non-free, retains some semantic independence, the meaning of such a unit can be derived from the meanings of its constituent words. The following expressions may be referred to such English phrases: to be at one's wits' end, to be good at something, to be a good hand at something, to have a bite, to come off a poor second, to come to a sticky end (coll.), to look a sight (coll.), to take something for granted, to stick to one's word, to stick at nothing, gospel truth, bosom friends

Semantic classification of phraseological units (V.V. Vinogradov) is based on the motivation of the units(Vinogradov,2006: 110).

1. Phraseological fusions are units whose meaning cannot be deduced from the meanings of their constituent parts. The meaning of PFs is unmotivated at a given stage of language development, e.g. red tape,

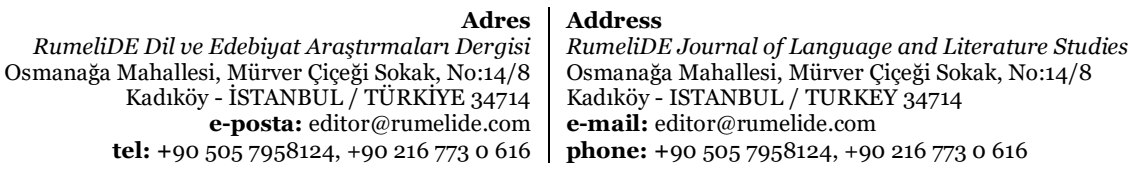


mare's nest (illusion, something that does not exist), My aunt! (here you go!, here's the thing!, wow!). The meaning of the components is completely absorbed by the meaning of the whole; (Vinogradov,2006: 85).

2. Phraseological units are expressions that meaning can be deduced from the meanings of their components; the meaning of the whole is based on the transmitted meanings of the components, e.g.

to show one's teeth (to be unfriendly),

to stand by one's weapons (refuse to change one's mind), etc.

These are motivated expressions.

3. Phraseological word combinations are not only motivated, but also contain one component used in the direct meaning, while the other is used metaphorically, for example, to meet requirements, to achieve success.

Prof. A.I. Smirnitsky (2007) classified PU as highly idiomatic set expressions functioning as word equivalents, and characterized by their semantic and grammatical unity. He suggested three classes of stereotyped phrases:

1. traditional phrases (nice distinction, rough sketch);

2. phraseological combinations (to fall in love, to get up);

3. idioms (to wash one's dirty linen in public);

The second group (phraseological combinations) fall into two subgroups:

1. one-top phraseological units, which were compared with derived words;

2. verb-adverb PUs of the type to give up, e.g. to bring up, to try out, to look up, to drop in, etc.

3. PUs of the type to be tired, e.g. to be surprised, to be up to, etc.

4. Prepositional substantative units, e.g. by heart.

5. two-top phraseological units, which were compared with compound words.

6. attributive-nominal, e.g. brains trust, white elephant, blind alley. Units of this type function as noun equivalents;

7. verb-nominal phrases, e.g. to know the ropes, to take place, etc.

8. phraseological repetitions, e.g. ups and downs, rough and ready, flat as a pancake. They function as adverbs or adjectives equivalents;

9. adverbial multi-top units, e.g. every other day. (Smirnitsky,2007: 210)

\section{I.4 Ways of forming phraseological units}

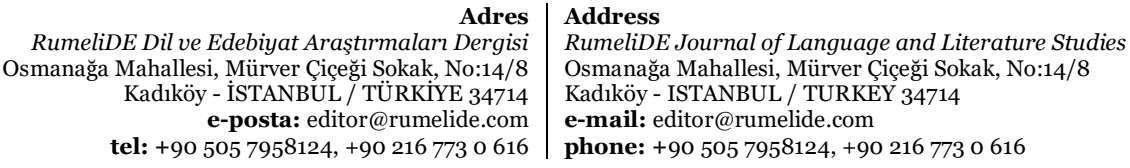

tel: +90 $5057958124,+902167730616$ 
Phraseological combinations in the works of researchers are also called "traditional", "phraseoloids", "stable combinations with fixed nomination", "analytical form of the English verb form", "combinations", "stable combinations". Phraseological unities are stable word combinations with a completely reinterpreted meaning. The individual words comprising it are semantically non-self-sufficient, and the meaning of each of the components is subordinated to the unity of the general figurative meaning of the phraseological expression as a whole, since the metaphor, on the basis of which the unit is built, is quite transparent.

In terms of their syntactic functions among the stable combinations are distinguished:

1) Verbal (verbal, i.e. performing the role of a verb): torunforone's (dear) life, toget (win) theupperhand, totalkthroughone'shat, tomakeasonganddanceaboutsomething.

2) Substantive (performing the role of a noun): ): dog's life, cat-and-dog life, calf love, white lie, tall order, birds of a feather, birds of passage, red tape, brown study.

3) Adjectival (performing the role of an adjective): high and mighty, spick and span, brand new, safe and sound, (as) cool as a cucumber, (as) nervous as a cat, (as) weak as a kitten, (as) good as gold (usually spoken about children), (as) pretty as a picture, as large as life, (as) slippery as an eel, (as) thick as thieves, (as) drunk as an owl (sl.), (as) mad as a hatter/a hare in March.

4) Adverbial (fulfilling the role of an adverb): high and low (as in They searched for him high and low), by hook or by crook, for love or money, in cold, in the dead of night, between the devil and the deep sea, to the bitter end, by a long chalk.

5) Interjective (fulfilling the role of an interjection): My God/ By Jove! ByGeorge! Goodness gracious! GoodHeavens! (Worrall , 2010: 38).

Phraseological combinations in the works of researchers are also called "traditional", "phraseoloids", "stable combinations with fixed nomination", "analytical form of the English verb form", "combinations", "stable combinations"

Phraseological unities are stable word combinations with a completely reinterpreted meaning. The individual words comprising it are semantically non-self-sufficient, and the meaning of each of the components is subordinated to the unity of the general figurative meaning of the phraseological expression as a whole, since the metaphor, on the basis of which the unit is built, is quite transparent.

Phraseological fusions are stable word combinations which are a semantically indivisible whole; unlike phraseological unities, they are completely demotivated, i.e. the meaning of the whole is not derived from the meanings of the individual words that make up the phraseological fusion. The semantic independence of the component words is completely lost, and the metaphor, on which the meaning shift is based, has already lost its clarity and transparency. Examples of such phraseological fusions are:

to come a cropper (to come to disaster); neck and crop (entirely, altogether, thoroughly, as in: He was thrown out neck and crop. She severed all relations with them neck and crop.); at sixes and sevens (in confusion or in disagreement); to set one's cap at smb. (to try and attract a man; spoken about girls and women); to leave smb. in the lurch (to abandon a friend when he is in trouble); to show the white feather (to betray one's cowardice); to dance attendance on smb. (to try and please or attract smb.; to show exaggerated attention to smb.)(Worrall ,2010: 35).

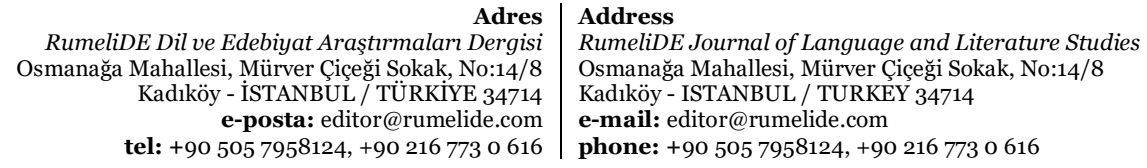
tel: $+905057958124,+902167730616$

phone: +90 505 7958124, +90 2167730616 
In terms of their syntactic functions among the stable combinations are distinguished:

1) Verbal (verbal, i.e. performing the role of a verb): torunforone's (dear) life, toget (win) theupperhand, totalkthroughone'shat, tomakeasonganddanceaboutsomething.

2) Substantive (performing the role of a noun): ):dog's life, cat-and-dog life, calf love, white lie, tall order, birds of a feather, birds of passage, red tape, brown study.

3) Adjectival (performing the role of an adjective): high and mighty, spick and span, brand new, safe and sound, (as) cool as a cucumber, (as) nervous as a cat, (as) weak as a kitten, (as) good as gold (usually spoken about children), (as) pretty as a picture, as large as life, (as) slippery as an eel, (as) thick as thieves, (as) drunk as an owl (sl.), (as) mad as a hatter/a hare in March.

4) Adverbial (fulfilling the role of an adverb): high and low (as in They searched for him high and low), by hook or by crook, for love or money, in cold, in the dead of night, between the devil and the deep sea, to the bitter end, by a long chalk.

5) Interjective (fulfilling the role of an interjection): My God/ By Jove! ByGeorge! Goodness gracious! GoodHeavens! (Worrall, 2010:38).

Structurally, Smirnitsky divides phraseological expressions into single-verse, double-verse and multi-verse, depending on the number of denominative words. For example, one-verb phraseologism is a compound of a non-nominal word or words with one denominative word.

A.I. Smirnitsky (2007) offers the following classification of phraseological units of the English language:

1. Verb-adverbial single-verb phraseological units with the coincidence of semantic and grammatical centers in the first component of the word combination, acting as equivalents of verbs, for example, to give up, to make out, to look for etc.;

2. Single-verse phraseological units of the type to be tired of, with the semantic center in the second component and the grammatical center in the first component of the word-combinations, acting also as verb equivalents;

3. Prepositional-noun single-noun phraseological units with the semantic center in the noun component of the word combination and with no grammatical center at all. They may act either as equivalents of adverbs (by heart, in time) or as equivalents of linking words (in order to, by means of) ++(Hornby,2004:120).

According to point of view G. B. Antrushina, O. V. Afanasyeva and N. N. Morozova (2001: 65), the traditional and oldest principle of classifying phraseological units is "thematic", or "etymological", which is the basis for classifying phraseological units according to their origin. They are classified according to the source of their origin, the sphere of human activity to which they belong, nature, natural phenomena, etc. The thematic principle of classifying phraseological units, considering only the origin and meaning of phraseological units, does not pay any attention to their linguistic characteristics, but allows us to consider them in terms of reflecting a particular subject area in the linguistic picture of the world.

Kunin (1981) points out that the existence of a word in a phraseological unit as a lexeme differs in a number of features compared to the existence of the same word with an independent lexical meaning outside the phrase. The number of forms peculiar to the components of the phraseological unit is fewer than the

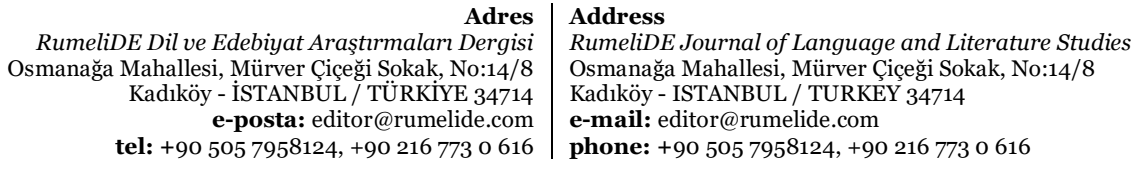


number of forms that the same words have outside the phrase. A characteristic feature of English verb phrases is the form change of the verb component or verb components in phrases with a conjunctive structure. The combination of forms in which a verb may be used as a part of another verb phrase may be different, but the number of forms is always limited (Kunin,1981: 120).

Phraseological units are stable word combinations characterized by a constant lexical composition and complicated semantics, the meanings of which are not divided into elements corresponding to the elements of the external form, and usually do not follow from the addition of meanings of individual elements of the phraseological unit. There is no unified classification of English phraseological units, since scientists divide phraseological units on the basis of different principles: structure, semantics, communicative function, etymology of phraseological units, approaches to their translation into other languages, etc. A characteristic feature of phraseological units is the presence of a smaller number of word forms in them in comparison with the word forms of their components, which are used as modifiable words in variable combinations.

\subsection{The Development of English Phraseology competence in the English Foreign Language}

\subsection{Typology of English phraseological units and borrowings}

Phraseology emerged relatively recently as an independent linguistic discipline. The subject and objectives, scope and methods of studying phraseology have not yet been clearly defined, and therefore have not received full coverage. Less developed than others are the questions about the main features of phraseological units in comparison with free word combinations, about the classification of phraseological units and their relation to parts of speech. On the basis of the existing methods of research in linguistics, "proper phraseological methods of analysis and description" are developed:

1. the method of identification - establishment of identities of words and syntactic constructions forming phraseological expressions with their free analogues;

2. the method of application, which is a variant of the identification method, the method of limited choice of variables, establishing distinct structural and semantic organizations of phraseology from combinations formed in accordance with regular patterns of choice and combination, etc. Phraseology offers different types of classifications of the phraseological composition of the language depending on the properties of phraseological units and methods of their study (Leaney, 2005: 99).

Well known, phraseological expressions arise from a free combination of words, which is used in figurative meaning. Gradually the figurative meaning is forgotten, erased, and the combination becomes stable.

In English, there are the following typologies of phraseological expressions:

1. a typology based on the grammatical similarity of the component composition of phraseological units.

a) Combination of an adjective with a noun:

Vicious circle - the enchanted circle

The Indian summer.

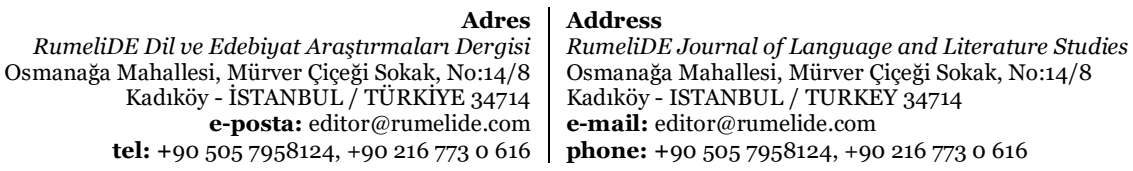


b) The combination of the prepositional-positional form of a noun with an adjective: Be on a good footing: To be on short terms with someone

c) Combination of a verb with a noun (with or without a preposition):

Come to one's senses - to take up the mind

Cock one's nose, to pull up one's nose.

d) Combination of a verb with an adverb:

To see through somebody.

Fly high. To be very ambitious

Get down to earth. To get down from the clouds to earth

e) Combination of a participle with a noun:

One's heart is bleeding

2. a typology based on the correspondence between the syntactic functions of phraseological units and the parts of speech with which they can be replaced.

a) Noun phraseological units: Swan-song. (in a sentence they function as a subject, a predicate, an adjunct; by the nature of connections with other words in the combination they can govern a member and be governed);

b) Verbal phraseological expressions

Hold one's ground - to hold one's ground very firmly, not to give up one's ground (in a sentence, they play the role of a predicate; in combination with other words, they can agree, govern and be governed)

c) Adjective idioms

In blooming health - blood with milk

They have the meaning of a qualitative characteristic and, like adjectives, appear in a sentence as a definition or as a noun part of a predicate);

d) Adverbial phraseological expressions: Up one's sleeves

(like adverbs, they characterize the quality of an action and act as circumstances in a sentence);

e) Interjection idioms: Good luck! (like interjections, such phraseological expressions express volition, feelings, acting as separate, undivided sentences).

\subsection{Teaching phraseological units as formulaic phrases}

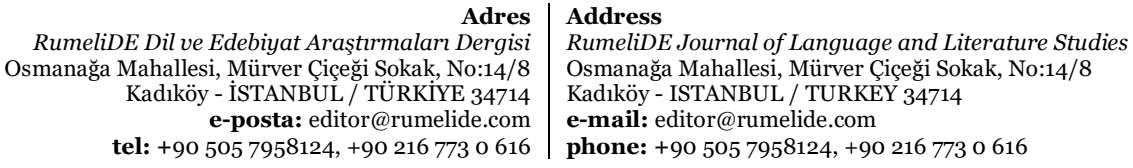


Various researchers have addressed the issue of how to implement and teach formulaic expressions in the classroom. Boers and Lindstromberg (2012) provided an exhaustive review of studies that have investigated which enhancement techniques have the potential to boost students' knowledge of formulaic expressions. Lewis (1993) stated that lexical approach helped students to use the formulaic expression. Boers (2006) also has consistently found positive long-term effects of having students' exploit formal properties of formulaic expressions, e.g., by asking students to pay attention and focus on sounding repetition. Other factors that have been found to contribute to students' learning formulaic expressions are translation activities and specific vocabulary activities (Laufer \&Girsai, 2008). According to the new state standards of foreign language, the mandatory minimum content of the basic educational programs, in addition to speech skills and language knowledge and skills, compensatory skills and learning and cognitive skills, include socio-cultural knowledge and skills. Sociocultural competence is a complex of knowledge about values, beliefs, behavioral patterns, customs, traditions, language, cultural achievements, characteristic of a certain society and occurs in the simultaneous process of teaching a foreign language and familiarizing a person with culture and folk traditions of the country of the studied language. One of the requirements for socio-cultural competence at the high school level is the understanding and ability to use basic phonemic and non-equivalent vocabulary as well as phraseological units. The stable formations of phraseological character include proverbs and sayings.

\subsection{The study of teaching phraseological units in EFL classes}

When examining textbook sets for primary and secondary schools, it is observed that communicative phraseological units of the English language are underrepresented and are not included in modern textbooks. Thus, a special system of exercises is needed to give learning a communicative orientation, which contributes to the formation of oral-speech skills of students, i.e. mastering, understanding and the ability of students to apply basic phraseological units in the process of communication in a foreign language.

While the teachers were teaching communicative phraseological units and the formation of oral-speech skills of students with the help of these speech units, they face the following tasks: to cause interest in phraseological units, the desire to know them and use them in the process of communication in a foreign language; to help children understand the content in general; to learn to recognize and understand the phraseological units in oral speech; to ensure their memorization. In order to implement all the above tasks, it is proposed to use the following system of work with phraseological units in foreign language lessons, which includes a set of illustrations depicting the essence of some phraseological units. These are the most common phraseological units that secondary school pupils can use in the process of communication. Here are some suggestions:

It is useful using the main stages of work with phraseological units, aimed at shaping pupils' oral-speech skills as:

1. students are offered to look carefully at the pictures and read the inscriptions corresponding to them;

2. assume what they mean and how they should be translated into Russian (at this stage students use linguistic guesswork);

3. read the phrase unit and match it to the picture and translate it word-for-word;

4. because word-for-word translation often sounds incongruous, pupils make their own assumptions about how the phraseological unit could be interpreted in relation to the subject of the picture;

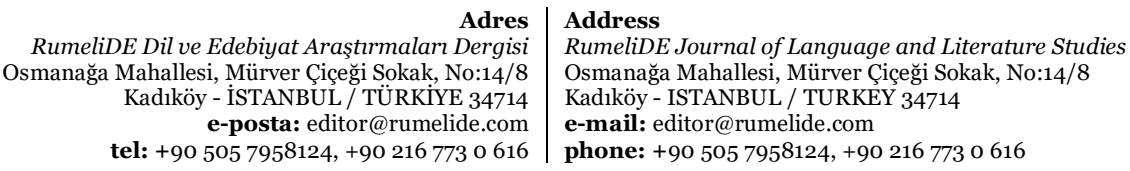


5. the teacher offers the students a situation using the given phraseological unit to listen to or read;

6. students express their options concerning the context (at this stage the teacher should suggest the communicative meaning of the phraseological unit);

7. write down the phraseological turn and its meaning in a special dictionary for communicative phraseological units of the English language;

8. students make (orally) sentences with this unit;

9. the teacher suggests that pupils create a dialogue or a situation using a certain phraseological unit;

10. at each subsequent stage the teacher uses techniques aimed at consolidation and creates conditional situations involving the use of phraseological units in speech.

However, not all phraseological units can be presented in the form of drawings, so the semantising of phraseological units with the help of visuals can be replaced by translation with a detailed explanation of the meaning and source of the given phraseological unit. In all subsequent stages, it is useful to work with phraseological units proceeds in the same way as with the use of visuals.

After several lessons on studying and consolidating phraseological units, a generalisation and systematisation lesson can be held, during which the teacher can help the students to divide the studied phraseological units into groups according to their topic or sphere of use, to give the task of composing a dialogue or a monologue using as many phraseological units or with certain phraseological units as possible. If the pupils are sufficiently linguistically prepared, a communicative activity (role play, storytelling or storytelling) should be carried out.

An analysis of the methodological literature has allowed us to identify examples of exercises which are more conducive to the development of oral language skills in a foreign language lesson:

\section{Find the best replacement for the highlighted words:}

Sony has made a killing on its popular Play Station line.-

\section{1. lost money on}

2. made a lot of money

\section{3. decided to stop producing}

Answer: №. 2. To make a killing - to make a lot of money.

\section{Choose the most appropriate answer to the sentence:}

Our company is in the red again this quarter. -

1. Congratulations! When`s the celebration party?

2. In the red again? I hope you don't go out of business!

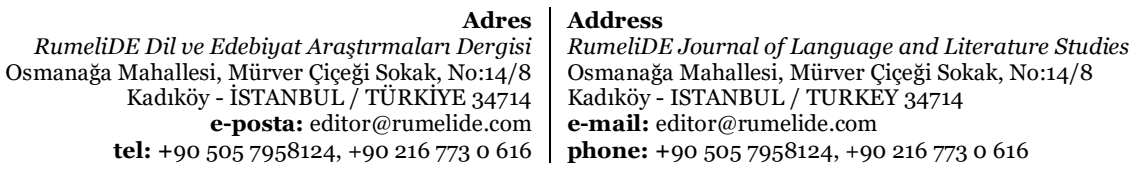


3. In the red? I hope you don't go out of business!

Answer № 2. the expression "in the red" means "incurring a loss", the expression "in the black" means "making a profit".

\section{Insert the missing words}

Martin was laid off from his job six months ago, and he still hasn't found a new position. He's ...jobs.-

1. among, 2. between, 3 . out of.

Answer № 2. "Between jobs" means "to be temporarily out of work, to be unoccupied".

\section{The group is divided into two teams. A sentence is written on the board:}

In 1985, the Coca-Cola Company released New Coke. It was a real dog and was in stores for only a few months. What does "a real dog" mean? -

1. commercial success. 2. a commercial failure. 3. a good deal.

Answer № 2 is commercial failure. Whoever translates the word combination correctly gets a point.

\section{The following exercise is designed to reinforce the phraseology:}

A student stands with his back to the blackboard. The teacher writes a phrase combination on the blackboard and the other pupils try to explain in English what the phrase means. The pupil at the blackboard should guess what the phraseology means from the description of their classmates.

For example, the word on the blackboard is "to break the news". The pupils in the classroom explain the phrase to their friend as follows: to make something known, to tell someone some important news. The pupil at the blackboard has to guess: to break the news - to tell the news.

6. A student chooses a blind card with a phraseology and gives a description of it without preparation.

The others try to guess the phraseology from the description. The one who guesses it first gets a point.

\section{The group is divided into two teams.}

The teacher writes 5-6 phrases suggested by the students on the board and then suggests that they make up a story and draw it on the board. For example: It's a deal! (I agree!); to have in mind; to move on; market share; to cost an aim and a leg; to play one`s card sight and so on. They are given about 10-15 minutes to prepare. Then the students of each team make up the situation on the blackboard and talk in English about what they have drawn. The team that does the best job wins.

All these exercises contribute to memorising phraseological units, developing spoken language and creative thinking.

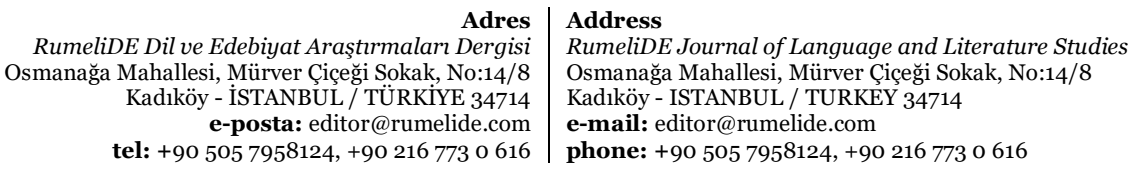


An exercise in which you have to find the meaning of the idioms is very useful. The idioms are presented in the story, the pupils may not know the meaning of the phraseological units, but they can determine from the context what meaning corresponds to the idioms presented in the left column.

It is known that the emotional factor plays an important role in teaching a foreign language. Emotional perception of the teaching material increases the effectiveness of learning. To make the learning process more interesting, we try to find humour in English phraseology. Many idioms look funny, create a comic effect, reveal unexpected sides of a concept. The teacher draws attention to the meaning of such phraseological expressions, which facilitates faster learning. For example: to hit the ceiling - to get angry or excited; to shake a leg - to hurry; white elephant - something useless; to pull the wool over one s eyes - to deceive, to dupe; a face so ugly it can stop a clock - ugly, repulsive face; as merry as a cricket - cheerful; to talk through one`s hat - to lie; as complacent as a cat - self-righteous.

Exercises to consolidate phrases can be done in pairs or as a whole group. Interesting exercises are as follows:

1) The teacher gives each student a piece of paper on which part of the phraseology is written. The task of the student is to locate another student who has the part of the sentence which ends the phraseology.

2) The teacher suggests situations, some of which allow the use of the idiom and some of which do not. He asks to determine whether the idiom fits the situation or not. Example: which of the following statements illustrates the idiom: to be on target - to achieve a desired goal - to be correct about something; For example:

1) A student who answers every question on a test correctly. Answer: He/she is on target.

2) A basketball player who makes $15 \%$ of his shots. Answer: He/she is not on target.

Working with phraseology of business English allows expanding lexical and phraseological vocabulary, introducing elements of excitement and diversity into the study of English, stimulates learning activities

During the internship we developed a set of exercises with the use of idioms. This complex is designed for 8 lessons (4 weeks of pregraduation practice) and was used in English lessons in Year 9 (see Appendix 1).

Thus, with the regular use of these techniques of work with phraseological units there is an opportunity to achieve certain results in the teaching of basic communicative speech units in order to form the oral-speech skills of schoolchildren.

\subsection{Result and analysis}

Experimental work was carried out on the basis of the Yessentuki MOU SOSH № 4, where the methodological association of teachers is represented quite a lot. The school has aesthetically designed foreign language rooms with many tables, diagrams and drawings. The institution lacks technical equipment. Analysis of textbooks and manuals on the English language allows us to state that there is no information on the problems of using phraseological units in oral speech in textbooks and manuals for the secondary level, which complicates the experimental research work to some extent.

The research was carried out in three stages.

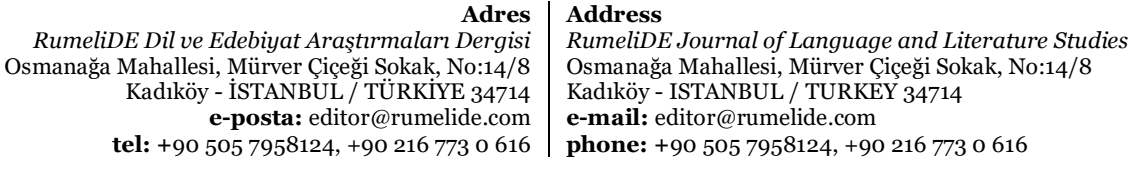


Stage I - ascertaining experiment. Purpose: to reveal the degree of pupils' awareness of phraseological units; to find out whether pupils use phraseological units in the process of communication.

Two groups of grade 9 pupils were selected for the conducting of the ascertaining experiment and they were interviewed. During the interviews it was found out that students know nothing about phraseology and phraseological units of the English language. Observation of the communication process in lessons showed that students do not use phraseological units in speech.

The main stage of the conducting of the ascertaining experiment was the testing of pupils on this problem. The test included two tasks (translation of sentences from English into Russian and choosing the correct answer).

I. Translate these sentences from English into Russian.

1. I shouldn't take this project, I bite off more than I can chew.

2. You have a bee in your bonnet just as you are crazy!

3. I wanted to buy a dress. And I liked this dress at once because good wine needs no bush.

4. My life is happy. I think I was born under a lucky star.

5. My friend is a doubting Thomas.

6. You like her, but she is the apple of Sodom.

7. He is very sly, but I know his Achilles' heel.

8. She is pleased and grins like a Cheshire cat.

9. It wasn't a calm family celebration; it was just a Donnybrook Fair!

10. I am off to Bedfordshire.

II. Choose the right variant of the translation.

1. the green - eyed monster

jealousy

green-eyed monster

green yearning

2. to rain cats and dogs

cats and dogs

pour from a bucket

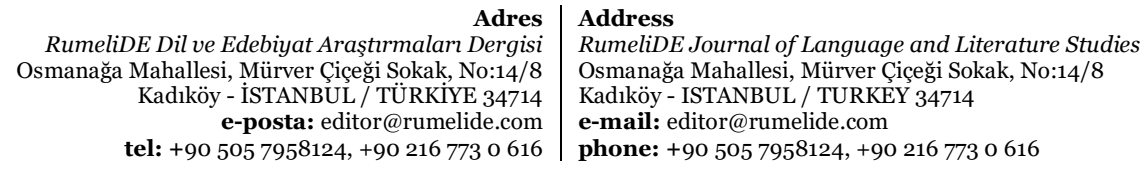


bath cats and dogs

3. to have butterflies in the stomach

have butterflies in stomach

be nervous

have a tummy ache

4. How goes the enemy?

What time is it?

How goes our enemy?

How goes the enemy?

5. Little pitchers have long ears

little pitchers have long ears

have sharp ears

small children like to listen to adults talking.

6. every dog has his day

there will be a feast in our street

every dog has his day

every dog has his day

7. the house that Jack built

the house that Jack built

story with repetition

Jack's house

8. to paint the lily

paint a lily

try to improve something already good

paint a lily 
9. to quarrel with one's bread and butter

quarrel with one's bread and butter

not even have bread and butter

give up a livelihood occupation

In this lesson we had a discussion with the students on the topic "What do you know about English phraseology? The children did a quiz to find out how well they knew about phraseology. They were allowed to use dictionaries to translate sentences. Pupils had difficulties in completing the tasks, the literal translation of sentences somewhat confused them and caused bewilderment.

The results of the pilot experiment are shown in Diagrams 1 and 2:

Results of the pilot experiment in the experimental group

Diagram 1

Task 1 Task 2

The results of the conducting experiment in the control group

Diagram 2

\section{Task 1 Task 2}

- Number of students who made no mistakes

- number of students who made 1-5 mistakes

- number of students with more than 5 mistakes

Summing up the results of the ascertaining experiment, we conclude that secondary school pupils are not aware of the basic phraseological units of the English language and, therefore, are not able to use them in the process of communication. But the students showed a keen interest in the topic of English phraseology during the conversation; the conversation held became a stimulus for students to study communicative phraseological units.

Stage II - formative experiment. Objective: to arouse students' interest in phraseological units as a means of communication; to investigate the practical significance of phraseological units in the formation of oralspeech skills of students.

For the formative experiment we chose the group of pupils who showed greater interest in the topic of English phraseology. The interest of pupils is explained by the fact that previously they met phraseological units, but they could not translate them.

During the formative experiment, a system of exercises using the phraseological units discussed in Appendix 1 was tested.

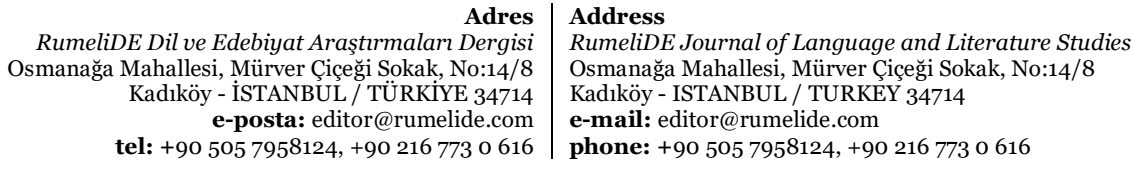


In the first lesson, the students were offered an exercise to identify phraseological units and translate them. The students tried to identify and translate these phraseological units verbatim and, naturally, the resulting translation sounded ridiculous and did not correspond to the actual translation. When they found out that the translation was wrong, the students looked puzzled but suggested new ways of semantizing the phraseological units (see Annex 1).

The next step was to offer the students listening situations using the phraseological units. After listening, the teacher presented the communicative meaning of the phraseological units, i.e. their authentic translation. When composing dialogues and sentences, some pupils had difficulties, so first they composed sentences with the given phraseological units in Russian and then translated them into English. Such type of exercises as matching was used. At the end of the lesson students were given special dictionaries of phraseological units of the English language, where they wrote down the expressions and their meanings new to them.

In the following lessons, techniques were used to reinforce the studied phraseological units and conditional situations involving the use of phraseological units in communication were created. In all subsequent lessons, the pupils were introduced to new phraseological units and carried out exercises of the type described in \$2.2. Pupils translated sentences, composed their own examples with the proposed phraseological units, listened to situations, and did exercises to relate phraseological units to their communicative meanings. All the tasks were carried out with interest, because in the process of working with phraseological units they learned a lot of interesting facts not only about the language itself, but also about the history of the English people and the history of the origin of some phraseological units. In the first lessons, it was very difficult to compose dialogues with certain phraseological units. But in the process of learning the phraseological units, most students overcame these difficulties.

During the formative experiment, pupils showed curiosity and activity, and a good psychological climate was established in the class.

At the eighth (final) lesson of the experiment the results of the work done became visible; pupils recognised by ear the previously learned phraseological units and made attempts to use them in speech. Pupils were asked to compose a dialogue or a monologue using as many of the studied phraseological units as possible, which most of them did well. Dialogues and situations were composed, although errors of a grammatical nature were made. All the pupils were actively involved in the communication process in the lesson. Some children were so interested in the topic that they discussed the studied phraseological units even during the breaks and came up to the teacher for additional explanations.

At each lesson the pupils were offered cards with situations for dramatisation. In the last, tenth lesson, a role-play was held, involving the use of most of the previously studied phraseological units in the process of communication.

Stage III - control experiment. Objective: to reveal the degree of effectiveness of the techniques used for the acquisition of phraseological units.

Both groups participating in the experiment are offered the following test:

I. Translate the sentences from English into Russian.

1. She got a present and grinned like a Cheshire cat.

Adres Address

RumeliDE Dil ve Edebiyat Araştırmaları Dergisi $\quad$ RumeliDE Journal of Language and Literature Studies

Osmanağa Mahallesi, Mürver Çiçeği Sokak, No:14/8 $\quad$ Osmanağa Mahallesi, Mürver Çiçeği Sokak, No:14/8

Kadıköy - ISTANBUL / TÜRKIYE 34714 Kadıköy - ISTANBUL / TURKEY 34714

e-posta: editor@rumelide.com e-mail: editor@rumelide.com

tel: +90 505 7958124, +90 2167730616 phone: +90 505 7958124, +90 2167730616 
2. This actress was born under a lucky star.

3. He didn't want to work and quarreled with his bread and butter.

4. Don't pain the lily!

5. I want to get rid of the green-eyed monster!

6. When I have an exam I always have butterflies in my stomach.

7. Helen was offended and said "Every dog has his day!"

8. Look at the window! It's raining cats and dogs!

9. I think he has no Achilles' heel at all!

10. You have a bee in your bonnet just as you are crazy!

II. Choose the right variant of translation.

1. a doubting Thomas

а. сомнительный Томас

b. Фома неверующий

c. Томас

2. the apple of Sodom

а. яблоко Содома

b. красивый, но гнилой внутри

с. яблочный пирог «Содом»

3. Bloody Mary
а. коктейль «Кровавая Мэри»
b. королева Мария
с. кровь Мэри

4. to be off to Bedfordshire

а. идти спать

b. ехать в Бедфордшир

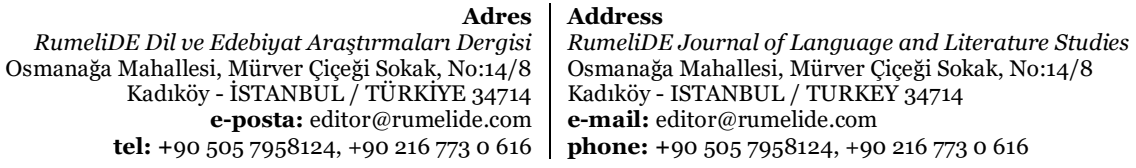


с. быть родом из Бедфордшира

5. the green-eyed monster
а. зеленоглазый монстр
b. скупость
с. ревность

6. to carry coal to Newcastle
а. ехать в Тулу со своим самоваром
b. носить уголь в Ньюкасл
с. ехать в Ньюкасл

7. to be born under a lucky star
а. быть самым счастливым в мире
b.родиться под счастливой звездой
с. наблюдать за звёздами

8. out of sight, out of mind
а. вне поля зрения
b.c глаз долой, из сердца вон
с.безумный

During the observation of the pupils it was noted that most of them had no difficulties in completing the tasks, as most of the given phrases were already familiar to the children. The form of the tasks also did not cause any perplexity or difficulty for the pupils.

Thus, pupils memorised a certain number of phraseological units, learned to use them in the process of communication and to recognise them in the flow of speech. In the experimental group, in the first task $10 \%$ of students made no mistakes, $60 \%$ of students made 1-5 mistakes (that is, there were inaccuracies in the translation of some phraseological units), $30 \%$ of students had more than 5 mistakes. The second task took less time, but all pupils had mistakes in their work: 70\% of them made 1-5 mistakes and 30\% made more than 5 mistakes. Some of the phrases were translated verbatim by pupils.

During the test in the control group students showed the following result: $10 \%$ of students made $1-5$ mistakes, $90 \%$ of students made more than 5 mistakes (the first task). In the second task all pupils gave wrong answers, i.e. $100 \%$ of pupils made more than 5 mistakes.

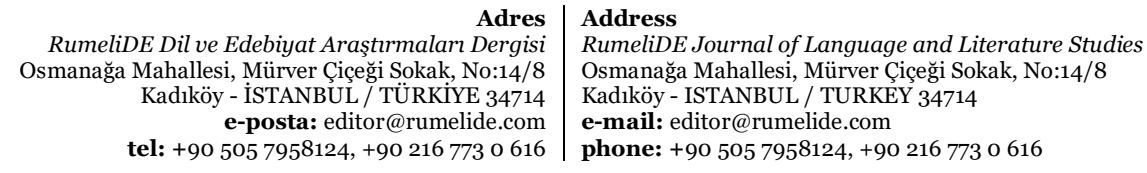


Compared to the control group, the experimental group showed better results in completing the test.

Summing up the results of the control experiment, we came to the conclusion: by applying the developed system of exercises, we obtained certain results which can be presented graphically. Consequently, the developed set of exercises is effective for use at the secondary level of school.

\section{Conclusion}

Phraseological units are one of the most effective means of developing oral-speech skills and, in particular, learners' speaking skills. The aim of teaching speaking using phraseological units is to develop students' ability to communicate orally in a variety of situations according to their real needs and interests, using phraseological units to enliven the process of communication. When teaching communicative phraseological units and the formation of oral speech skills of students with the help of these speech units, the teacher faces the following tasks: to arouse interest in phraseological units, the desire to know them and use them in the process of communication in a foreign language; to help children understand the content in general; to learn to recognize and understand the phraseological units in oral speech; to ensure their memorization.As a result of the experimental work we came to the conclusion that by applying the developed system of exercises we obtained certain results which can be represented graphically. Consequently, the developed set of exercises is effective for use at the secondary level of school. The phraseological fund of the English language is so large that a complete study of it would not fit into the framework of this work. Nevertheless, by the example of the examined phraseological units one can clearly imagine how diverse in their semantics and expressiveness the phraseological units of the modern English language are. Thanks to the literary works of writers and poets, both in Great Britain itself and around the world, the English language nowadays has a huge number of phraseological expressions. But, we should not forget that from the history and culture of different countries of the world a huge number of phraseological expressions also came into the English language. The phrase "to enrich with phraseological units" is often used in the work. It must be said that this is not a simple pattern, because phraseology is the treasury of the language, and phraseological units in the language are the wealth. Phraseological expressions not only reflect the culture and life of a particular language, but also help to make the speech most expressive and emotional.

Phraseology is an extremely complex phenomenon, the study of which requires its own method of research, as well as the use of data from other sciences - lexicology, grammar, stylistics, phonetics, language history, history, philosophy, logic and country studies. Phraseological units are considered as a means of shaping the oral-speech skills of pupils. The possibilities of teaching speaking using idioms are investigated. As a result of the theory analysis a set of exercises with the use of phraseological units is developed. These exercises were applied in practice at the secondary level of education in the course of experimental research work.

Reflecting the theory into practice, it was possible to arouse students' interest in phraseological units, a desire to know them and use them in the process of communication in a foreign language; to help children understand the meaning of phraseological units in general; to teach them to recognise them in the flow of speech and use them in communication. It was not possible to ensure that all the phraseological units are memorised by the pupils, the reason being the short time available for the experimental research work.

According to the results of the experiments we conclude that the developed set of exercises is useful and effective for work at school in the process of forming communication skills, in particular, oral speech skills,

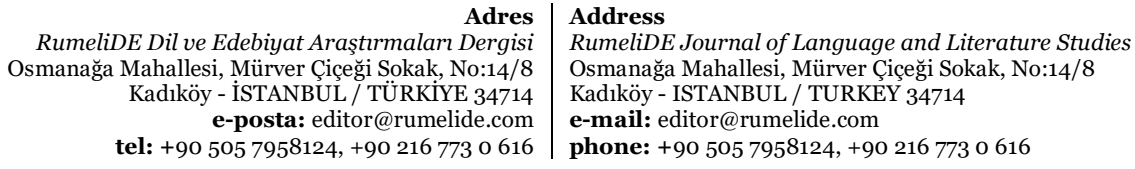


using communicative phraseological units. The results of the experimental-research work confirm the hypothesis put forward earlier.

Summing up and taking into account the set tasks, it can be said that phraseology in modern English is very rich in form and semantics and is developing quite rapidly. Phraseological units saturate speech, making it more vivid and lively. The phraseological fund provides the enrichment of the literary language with new expressive possibilities and means. Comprehensive study of the phraseological system of modern English allows us to penetrate more deeply into the complex and diverse life of phraseological units, to get an idea of their basic structural-semantic types, to learn the sources of their origin and the meaning of any phenomena in the modern world.

\section{References}

Antrushina, G.B. (2001). Lexicology of the English language: a textbook for students / G.B.

Antrushina,.O. V. Afanasyeva, N.N. Morozov. - Moscow: Bustard.- 299 p https://www.acade_english_lexicologymia.edu.

Arnold W. (2010). Extended, Embodied Cognition and Second Language Acquisition, Volume 31, Issue 5.- 299 p.https://doi.org/10.1093/applin/amq009.

ArutyunovaN.D.(1990) Diskurs // Linguistic Encyclopedic Dictionary. - M., - 260p.

Atkinson, J.(2010). Problematic Idiomatic Attic. - 599 p.

AmosovaN.N.(1963). Basics of English Phraseology-Leningrad,-123, https://www.booksite.ru/fulltext/amosova/text.pdf.

BimI.L.(1996) Objectives of teaching a foreign language in the framework of the basic course // Foreign languages at school - № 1.

Boers, F., \& Lindstromberg, S. (2009). Optimizing a lexicalapproachtoinstructedsecondlanguageacquisition. Palgrave-Macmillan.

Boers, F., \& Lindstromberg, S. (2012). Experimentalandinterventionstudiesformulaicsequencesin a secondlanguage. AnnualReviewofAppliedLinguistics, 32, 83-110.

Burger H.(2007). Phraseologie: An International Handbook of Contemporary Research. Berlin: Schmidt.

Kunin, A. V. (2006). Phraseology of modern English. - M .: International relations.

Kunin A.V. (1981) English phraseology. - Theoretical course., - Moscow.

KuninA.V.(1996). English : A Course in Phraseology of Modern English.-Moskow : VysshajaShkola. 381p.

Lewis, M. (1993). Thelexicalapproach: Thestateof ELT andthewayforward. Hove, England: LanguageTeachingPublications.

Rebeka. L. (1990). Oxford. National library of Australia.https://trove.nla.gov.au/work//( viz. 30.03.2021)

RyzhkovaV.V.(1996). Zum Problem des Studiums von Ausdruckseinheiten im modernen Englisch (zur Formulierung der Frage) // Visn. Kharkiv. un-tu. - Kharkiv, Nr. 386.

Smirnitsky A.I. (2007). Lexicology of the English language. - M .: Pedagogika. -- 255 p.

Smith L.P. (2008). Phraseology of the English language. - Moscow: Nauka. .- 179 p.

Shansky N.M. (1957). The main properties and methods of stylistic use of phraseological turns in the Russian language. pp. 32-37.

The New Oxford Thesaurus of English.(2000). Oxford: -Oxford University Press.

The New Oxford American Dictionary.(2005). Oxford: -Oxford University Press, 2005. 196 p.

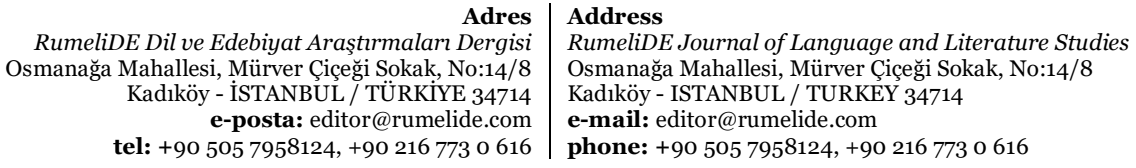


Vinogradov, V.V. (2006). On the main types of phraseological units in the Russian language. - Moscow: Nauka. $-190 \mathrm{p}$.

Worrall A.J. (2010). English idiomatic expressions. - M .: Fiction. -37-42p.

\section{Appendix}

A set of exercises using

Phraseological units

Exercise 1. Identify which of the word combinations highlighted are phraseological units.

1. Where do you think you lost your purse?

2. When losing the game one shouldn't lose one's temper.

3. Have a look at the reverse side of the coat.

4. The reverse side of the medal is that we'll have to do it ourselves.

5 . Keep the butter in the refrigerator.

6 . Keep an eye on the child.

7. He threw some cold water on his face to wake up.

8. I didn't expect that he would throw cold water upon our project.

9. The tourists left the beaten track and saw a lot of interesting places.

10. The author leaves the beaten track and offers a new treatment of the subject.

11. I don't want to have a busman's holiday1.

12. Let's stretch a point2 for him.

13. The weak go to the wall3.

14. She looks as if butter wouldn't melt in her mouth

1 have a busman's holiday - spend time at work

2 stretch a point - not very strictly enforce the rules, make allowances for smth.

3 go to the wall - lose out

4 look as if butter wouldn't melt in one's mouth - look deceptively innocent

Exercise 2. Using the dictionary, find the meaning of the following homonymic variable word combinations and phrases. Tell what their semantic and phonetic differences are.

blue book; black ball; blue bottle; hot head; hot house; dancing master; flying man; blue stocking; shooting party; skiing instructor.

Exercise 3. Translate the sentences using the dictionary. Tell me which of the words highlighted are phraseological units.

1.He looked round but saw nothing suspicious. 2. I'll show you round, I know the city. 3 . Who can bear out your words? 4. He heard the noise and rushed out. 5. Step aside. 6. It's late. I think I'll turn in. 7. He is not to be taken in so easily. 8. What brought about the crisis? 9. Don't worry, the sick man will pull through. 10. She let down the bucket into the well. 11. He won't let you down. 12. 'Is Mr. Todd in?' 'No, he is out.' 13. You are all in. Have a rest. 14. He is all out to get the prize.

Exercise 4: Create a dialogue using one of the following situations:

Jane is going to visit theatre. But she doesn't want to go there alone, so she asks Kate to make her a company. Unfortunately theatre is not Kate's cup of tea...

Peter and Mike are talking about Jim's behavior last weekend. He was very rude to his friends. Use the proverb "Handsome is that handsome does" in your dialogue.

Helen never puts off till tomorrow what she can do today/ She always says: tomorrow is another day and another deeds.

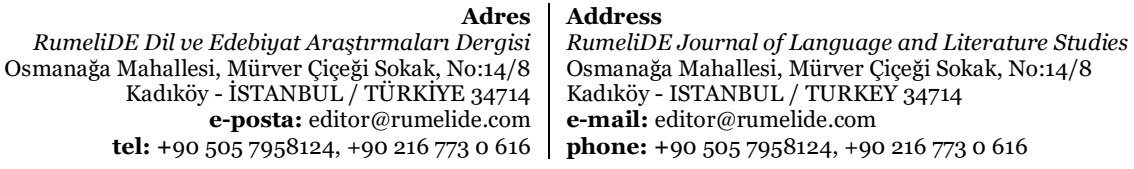

RumeliDE Journal of Language and Literature Studies Osmanağa Mahallesi, Mürver Çiçeği Sokak, No:14/8

Kadıköy - ISTANBUL / TURKEY 34714

e-mail: editor@rumelide.com

phone: +90 505 7958124, +90 2167730616 